\title{
Mycelial Growth Performance of Three Species of Pleurotus on Coconut Water Gelatin
}

\author{
Jacob JKS ${ }^{1 *}$, Kalaw SPK ${ }^{1,2}$ and Reyes RG $^{1,2}$ \\ ${ }^{1}$ Center for Tropical Mushroom Research and Development, Central Luzon State University, Science City of Munoz, Nueva \\ Ecija, Philippines. E-mail: james.jacobmsc@gmail.com \\ ${ }^{2}$ Department of Biological Sciences, College of Arts and Sciences, Central Luzon State University, Science City of Munoz, \\ Nueva Ecija, Philippines
}

Jacob JKS, Kalaw SP, Reyes RG 2015 - Mycelial Growth Performance of Three Species of Pleurotus on Coconut Water Gelatin. Current Research in Environmental \& Applied Mycology 5(3), 263-268, Doi 10.5943/cream/5/3/9

\begin{abstract}
Pleurotus, commonly known as oyster mushroom, is a wood rotting mushroom that naturally grows on decaying logs. This mushroom has been cultivated using saw dust based substrate formulation. This study was undertaken to evaluate the growth performance of Pleurotus citrinopileatus, Pleurotus djamor and Pleurotus salmoneostramineus on coconut water gelatin and different physical factors such as $\mathrm{pH}$, aeration, illumination and temperature conditions. Coconut water gelatin supported the mycelial growth of the three species as indicated by the luxuriant mycelial growth. Pleurotus citrinopileatus recorded fastest and shortest mycelial growth $(90 \mathrm{~mm})$ after six days of incubation while Pleurotus salmoneostramineus showed slower mycelial growth $(63.55 \mathrm{~mm})$, thick mycelial density and longest incubation period of eight days. Moreover, the three species grew best in $\mathrm{pH}$ 8.0, incubated either sealed or unsealed, both dark and lighted conditions at room temperature.
\end{abstract}

Key words - coconut water - growth performance - physical factors - Pleurotus

\section{Introduction}

Mushrooms have long been valued and highly flavorsome and nutritional foods by many societies. In the Orient, it has long been recognized that certain edible and non-edible mushrooms can have profound health benefits. The medicinal mushrooms are consumed whole or preferably as concentrated extracts. Mushrooms can also be used as dietary supplements (Salvador 2009). Pleurotus mushrooms as one of the most versatile mushrooms are easy to cultivate and common all over the world.

Recently, in most part of tropical countries, coconut water is being consumed as beverage with health benefits that contains sugar, dietary fiber, proteins, antioxidants, vitamins and minerals and provides an isotonic electrolyte balance. Researches revealed that coconuts may help benign prostatic hyperplasia (De Lourdes et al. 2007) and virgin coconut oil reduces total cholesterol, triglycerides, phospholipids, LDL and VLDL cholesterol levels and increased HDL cholesterol in serum and tissues (Kuntiya et al. 2004).

Since mushrooms have the potential to be utilized in practical agricultural wastes and Philippines, as the largest producer of coconut producing 19.5 million tons per annum (Leonard et al. 2011) they can be cultivated widely using coconut-based substrate. With the aim of establishing an 
efficient and low-cost culture media that can support the growth of secondary mycelia of three different species of Pleurotus mushrooms, this study was conducted.

\section{Materials \& Methods}

\section{Revival of culture and preparation of mycelial discs}

Agar blocks of approximately $10 \mathrm{~mm}^{2}$ x $3 \mathrm{~mm}$ from the pure stock culture of $P$. citrinopileatus, $P$. djamor and $P$. salmoneostramineus (from the culture collection of the Center for Tropical Mushroom Research and Development (CTMRD), Science City of Munoz, Nueva Ecija, Philippines were transferred aseptically into sterilized potato sucrose gelatin (PSG) plates. Culture plates were incubated at ambient room temperature to allow growth of the secondary mycelia. After 7 days of incubation, the mycelial discs were prepared using flame sterile $10 \mathrm{~mm}$ diameter cork borer in the revived culture which served as source of inoculum.

\section{Influence of nutritional factors}

The nutritional requirements of $P$. citrinopileatus, $P$. djamor and $P$. salmoneostramineus was evaluated using young coconut water and mature coconut water. The media were adjusted to $\mathrm{pH} 6.0$, sterilized at $15 \mathrm{psi}, 121^{\circ} \mathrm{C}$ for 20 minutes and dispensed on a sterile Petri plates. To ensure uniformity in the age of inoculum, a 7-day old pure culture of mycelia was used for the evaluation of the two culture media. A 10-mm diameter mycelial discs were prepared and centrally inoculated on the plated medium. The inoculated plates were sealed with laboratory film and incubated at ambient room temperature $\left(32^{\circ} \mathrm{C}\right)$ under an alternating light and dark conditions. Measurement of growth was done daily until total ramification of each medium was attained with three replicates each setup. Mycelial density was also recorded.

\section{Influence of physical factors}

The optimum medium from the previous evaluation, was adjusted to different $\mathrm{pH}$ levels such as $\mathrm{pH} 6.0,6.5,7.0,7.5$ and 8.0 using $1 \mathrm{M} \mathrm{NaOH}$ or $0.1 \mathrm{M} \mathrm{HCl}$ prior to sterilization. Approximately 10$\mathrm{mm}$ diameter fungal discs from a 7-day old pure culture of three different Pleurotus strains were inoculated on the plated media with different $\mathrm{pH}$ levels. From the most suitable medium, the inoculated plates of $P$. citrinopileatus, $P$. djamor and $P$. salmoneostramineus were sealed with laboratory film twice and the other setup unsealed to determine aeration requirements. The plates were incubated at room temperature to allow total ramification of mycelia. The most appropriate medium, $\mathrm{pH}$ and aeration were used to evaluate the influence of illumination on mycelial growth. Under lighted condition, the inoculated plates were incubated in a chamber with artificial light (322.92 lumens ${ }^{-2}$ ) at an ambient room temperature. Finally, the best nutritional and physical conditions which were previously determined were incorporated in determining the best temperature required for mycelial growth. Culture plates were incubated at different temperature conditions: room temperature $\left(32^{\circ} \mathrm{C}\right)$, air-conditioned $\left(23^{\circ} \mathrm{C}\right)$ and refrigerated $\left(9^{\circ} \mathrm{C}\right)$. The diameter of mycelial of mycelial growth of $P$. citrinopileatus, $P$. djamor and $P$. salmoneostramineus as influenced by the different physical requirements of the media, was measured and recorded as well as the mycelial density.

\section{Statistical Analysis}

The experiment was laid out following the completely randomized design. All the data collected were analyzed using one way ANOVA. Means were compared using least significant difference.

\section{Results and Discussion}

\section{Influence of nutritional factors}

Mycelium is the vegetative part of fungi that obtains nutrients from the substrate (Parmasto 1987). Evaluation of the nutritional content of the medium is necessary to regulate the best conditions that will favor the proficient growth of mushroom species (Ohira 1990). In this study, the mycelium of 
the three Pleurotus species namely, $P$. citrinopileatus, $P$. djamor and $P$. salmoneostramineus were cultured using young and mature coconut water incorporated with $2 \%$ gelatin. Table 1 and Figure 1 shows the mycelial diameter of the three species of Pleurotus cultured in coconut water media. Mycelial growth of the mushrooms were observed in both young coconut water gelatin and mature coconut gelatin. However, significantly larger mycelial diameter was observed in mature coconut water gelatin compared to the young coconut water gelatin. The significant difference in the mycelial growth response of Pleurotus on young coconut water gelatin and mature coconut water gelatin could be attributed to the nutritional content of the coconut water. Santoso et al. (1999) reported that the mature coconut water contains $92 \%$ sucrose, while young coconut water contains minimal amount of glucose and fructose making it not suitable for the cultivation of the mycelia. Many researches have been steered the use of coconut water as an effective media that supports mycelial growth of different mushroom species (Radenahmad et al. 2009). The result of the present study is congruent with the findings of De Leon et al. (2013) who reported the suitability of mature coconut water as a culture medium for Lentinus squarrosulus and Polyporus grammocephalus. Moreover, Reyes et al. (2009) reported that coconut water could stimulate the growth of Schizophyllum commune with subsequent production of schizophyllan.

Table 1 Influence of nutritional and physical factors on the growth response of the mycelia of three different Pleurotus species after 6 days of incubation.

\begin{tabular}{llcc}
\hline Nutritional/Physical Factors & P.citrinopileatus & $\begin{array}{c}\text { Growth response of the mycelia (mm) } \\
\text { P.djamor }\end{array}$ & P.salmoneostramineus \\
\hline Media & & & \\
Young Coconut Water & $30.57 \pm 1.47^{\mathrm{a}}$ & $15.28 \pm 1.16^{\mathrm{a}}$ & $20.82 \pm 1.20^{\mathrm{a}}$ \\
Matured Coconut Water & $61.89 \pm 2.79^{\mathrm{b}}$ & $78.38 \pm 2.45^{\mathrm{b}}$ & $89.16 \pm 0.76^{\mathrm{b}}$ \\
pH & & & \\
6.0 & $34.65 \pm 0.86^{\mathrm{a}}$ & $21.87 \pm 0.50^{\mathrm{a}}$ & $51.41 \pm 0.66^{\mathrm{a}}$ \\
6.5 & $54.71 \pm 0.67^{\mathrm{b}}$ & $25.70 \pm 2.65^{\mathrm{a}}$ & $52.71 \pm 1.94^{\mathrm{a}}$ \\
7.0 & $74.05 \pm 1.72^{\mathrm{c}}$ & $57.00 \pm 0.84^{\mathrm{b}}$ & $55.48 \pm 1.18^{\mathrm{b}}$ \\
7.5 & $82.97 \pm 1.87^{\mathrm{d}}$ & $48.91 \pm 3.22^{\mathrm{c}}$ & $75.37 \pm 1.03^{\mathrm{c}}$ \\
8.0 & $90.00 \pm 0.00^{\mathrm{e}}$ & $82.74 \pm 3.87^{\mathrm{d}}$ & $90.00 \pm 0.00^{\mathrm{d}}$ \\
Aeration & & & \\
Non-aerated & $89.04 \pm 0.66^{\mathrm{a}}$ & $89.48 \pm 0.50^{\mathrm{a}}$ & $88.96 \pm 0.47^{\mathrm{a}}$ \\
Aerated & $89.24 \pm 0.77^{\mathrm{a}}$ & $89.30 \pm 0.60^{\mathrm{a}}$ & $89.74 \pm 0.25^{\mathrm{a}}$ \\
Illumination & & & \\
Lighted & $89.07 \pm 0.82^{\mathrm{a}}$ & $88.86 \pm 0.96^{\mathrm{a}}$ & $88.88 \pm 0.95^{\mathrm{a}}$ \\
Total Darkness & $89.00 \pm 0.67^{\mathrm{a}}$ & $88.75 \pm 1.73^{\mathrm{a}}$ & $89.26 \pm 0.25^{\mathrm{a}}$ \\
Temperature & & & \\
Room Temperature $\left(32^{\circ} \mathrm{C}\right)$ & $89.39 \pm 0.72^{\mathrm{c}}$ & $89.31 \pm 0.59^{\mathrm{c}}$ & $89.33 \pm 0.75^{\mathrm{c}}$ \\
Airconditioned $\left(23^{\circ} \mathrm{C}\right)$ & $35.38 \pm 2.07^{\mathrm{b}}$ & $35.42 \pm 2.38^{\mathrm{b}}$ & $45.55 \pm 1.47^{\mathrm{b}}$ \\
Refrigerated $\left(9^{\circ} \mathrm{C}\right)$ & $10.00 \pm 0.00^{\mathrm{a}}$ & $10.00 \pm 0.00^{\mathrm{a}}$ & $10.00 \pm 0.00^{\mathrm{a}}$ \\
Mycelial Density & +++ & +++ & +++ \\
\hline
\end{tabular}

In Table: Values are the mean \pm SD of the secondary mycelia, and means having the same letter of superscript in the same column are insignificantly different from each other at $5 \%$ level of significance and mycelial density were evaluated as: very thin $(+)$, thin $(++)$, thick $(+++)$, very thick $(++++)$

\section{Influence of physical factors on the growth performance of three different Pleurotus species}

After the establishment of the appropriate nutritional requirement for the successful cultivation of the mycelia, environmental conditions including $\mathrm{pH}$ (acidity and basicity) of the substrate, aeration, illumination and temperature was evaluated. Table 1 presents the mean mycelial diameter of the three Pleurotus species at different $\mathrm{pH}$ levels, aeration, and illumination and temperature conditions. In all species, mature coconut water gelatin with a $\mathrm{pH}$ of 8.0 recorded the highest mean mycelial diameter after 6 days of incubation while the lowest mean mycelial diameter was noted in a medium with pH 6 . This result suggests that Pleurotus prefers slightly alkaline medium. In contrast with the results of Dulay et al. (2012), Lentinus tigrinus was best grown on coconut water gelatin at $\mathrm{pH} 7.5$. 


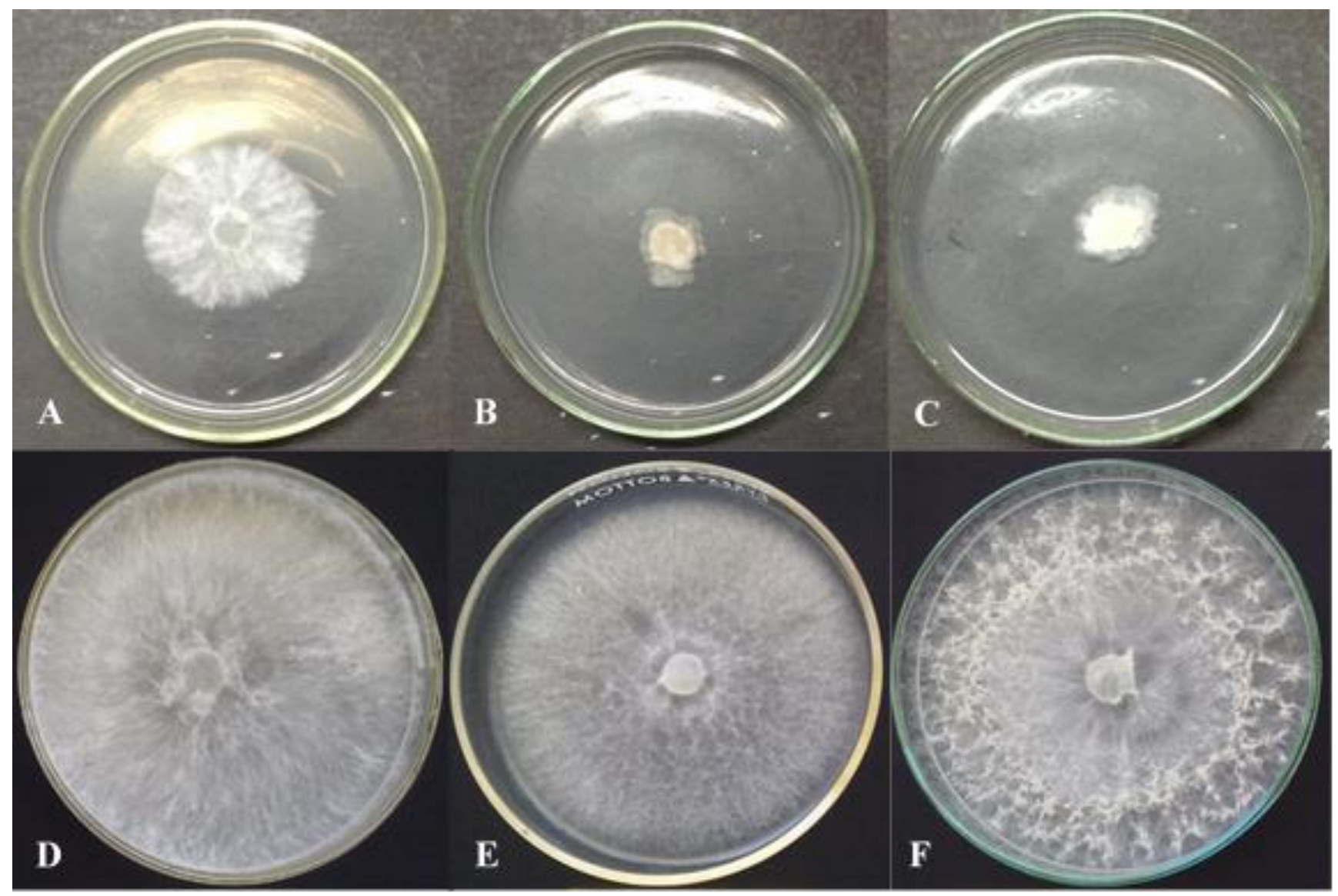

Fig. 1 - Plate culture of P. citrinopileatus, P.djamor, P.salmoneostrmineus using young coconut water gelatin $(\mathrm{A}, \mathrm{B}, \mathrm{C})$ and mature coconut water gelatin $(\mathrm{D}, \mathrm{E}, \mathrm{F})$.

$P$. djamor and $P$. citrinopileatus incubated in non-aerated or oxygen-deprived plate produced larger mycelial diameter while $P$. salmoneostramineus exhibited wider mycelial diameter in aerated plate. However, statistical analysis showed no significant difference between the two aeration conditions. This result indicates that the mycelia of these mushroom species can grow luxuriantly inboth conditions. Similar result was obtained by Dulay et al (2012) who reported Lentinus tigrinus can be incubated in either non-aerated or aerated condition. However, Reyes et al. (2009) disclosed that Coprinus comatus grew best on a non-aerated condition.

Illumination is another important physical factor to be considered in mushroom cultivation. In this study, the inoculated plates were incubated in dark and lighted conditions. $P$. citrinopileatus and $P$. djamor incubated in lighted condition exhibited larger mycelial diameter while $P$. salmoneostramineus exposed in dark condition produced larger mycelial diameter However, statistical results revealed no significant difference in mycelial diameter in both conditions indicating that the mushrooms can be incubated in either lighted or dark condition. The result of the present study conforms with the result obtained by Reyes et al (2009) that light and dark conditions did not affect the mycelial growth of Schizophyllum commune and basidiospore germination of Volvariella. volvacea. However, Chang and Miles (1989) reported that lighting could induce the normal development of mushroom fruiting body.

The present study also evaluated the influence of temperature on the growth of the three Pleurotus species. It can be seen in Table 1 that Pleurotus mushrooms incubated in room temperature $\left(32^{\circ} \mathrm{C}\right)$ produced significantly higher mean mycelial diameter compared to the other temperature conditions. No mycelial growth was noted in refrigerated condition. The results of Bulseco et al. (2005) contradicts the results obtained from this present study which stated that $S$. commune is best grown on airconditioned set-up. Moreover, the insensitivity of Pleurotus species to cold temperatures proves that it is best grown on tropical conditions. Kong (2004) from his subsequent studies on the temperature 
requirement of Pleurotus mushrooms stated that the optimum temperature range to grow these kind of mushroom is between $25-30^{\circ} \mathrm{C}$ while the season to best grow these species is during summer and fall. Based on the significant results obtained, it is established that the three Pleurotus species require optimum nutritional and physical factors for efficient mycelial growth that is very necessary in generating production technologies for these species.

\section{Acknowledgement}

This study was supported by the Department of Science and Technology thesis grant in the Philippines. The authors would like to thank Center for Tropical Mushroom Research and Development staffs, the MSc. Biology class of 2014 and their families for their unending support.

\section{References}

Bulseco MGM, Abella EA, Reyes RG. 2005 - Morphogenesis of Schizophyllum commune, a wild edible mushroom of Mt. Nagpale, Abucay, Bataan, Philippines. Journal of Nature Studies 4(1): $20-28$.

Chang S, Miles P. 1989 - Edible mushrooms and their cultivation. CRC Press, Inc. 41-78.

De Leon AM, Reyes RG, Dela Cruz TEE. 2013 - Lentinus squarrosulus and Polyporus grammocephalus: Newly Domesticated, Wild Edible Macrofungi from the Philippines. PHILIPPINE AGRIC SCIENTIST ISSN 0031-7454, December 2013.

De Lourdes V, Molina M, Más V, Carbajal D, Marrero D, González V, Rodríguez E. 2007 - "Effects of coconut oil on testosterone-induced prostatic hyperplasia in Sprague-Dawley rats". Journal of Pharmacy and Pharmacology 59 (7): 995-999.doi:10.1211/jpp.59.7.0012. PMID 17637195

Dulay RMR, Parungao AG IV, Kalaw SP, Reyes RG. 2012 - Aseptic cultivation of Coprinus comatus (O. F. Mull.) Gray on various pulp and paper wastes. Mycosphere 3(3), 392-397

Dulay, RMR., Kalaw, SP., Reyes, RG, Cabrera, EC, Alfonso, NF. 2012 - Optimization of Culture Conditions for Mycelial Growth and Basidiocarp Production of Lentinus tigrinus (Bull.) Fr., A New Record of Domesticated Wild Edible Mushroom in the Philippines. PHILIPP AGRIC SCIENTIST. ISSN 0031 - 7454 September 2012.

Kong WS. 2004 - Descriptions of Commercially Important Pleurotus Species. Chapter 4. Korea Rural Development Administration. Mushroom Growers Handbook 1, Oyster Mushroom Cultivation. 2004 Mushworld

Kuntiya A, Hanmoungjai P, Techapun C, Sasaki K, Seesuriyachan P. 2010 - Influence of pH, sucrose concentration and agitation speed on exopolysaccharide production by Lactobacillus confusus using coconut water as a raw material substitute. Int J Sci Technology 2010, 4:318-330

Leonard EC, Perkins EG, Cahn A. 1999 - Proceedings of the World Conference on Palm and Coconut Oils for the $21^{\text {st }}$ Century : sources, processing, application and competition. The American Oil Chemist Society. Pp. 21. ISBN 978-0-935315-99-8. Retrieved 15 November 2011.

Ohira, I. 1990 - "A revision of the taxonomic status of Pleurotus citrinopileatus". Reports of the Tottori Mycological Institute 28: 143-150.

Parmasto, E. 1987 - "Pleurotus citrinopileatus, one of the favourites". Mycologist 1 (3): 106107.doi:10.1016/S0269-915X(87)80076-9

Radenahmad N, Saleh F, Sawangjaroen K, Rundorn W, Withyachumnarnkul B, Connor JR. 2009 Young coconut juice significantly reduces histopathological changes in the brain that are induced by hormonal imbalance: a possible implication to postmenopausal women. Histology \& Histopathology. 24(6):667-74, 2009 Jun. UI: 19337965

Reyes RG, Lopez LLMA, Kumakura K, Kalaw SP, Kikukawa T, Eguchi F. 2009 - Coprinus comatus, a newly domesticated wild nutraceutical mushroom in the Philippines. Journal of Agricultural Technology 2009 Vol.5(2): 299-316. Available online http://www.ijat-rmutto.com . ISSN 16869141 
Salvador DGD. 2009 - DNA Profile and Anti-bacterial Properties of G. lucidum (Fr. Karst).

Undergraduate Thesis, Department of Biological Sciences, College of Arts and Sciences, Central Luzon State University, Philippines. 2009.

Santoso U, Kubob K, Otac T, Tadahiro T, Akio M. 1999 - Nutrient composition of kopyor coconuts (Cocos nucifera L.). Elsevier Journal Article. Received 11 August 1995, Revised 27 October 1995, Accepted 27 October 1995, Available online 19 March 1999 